Meta

Journal des traducteurs

Translators' Journal

\title{
Interpreting into an SOV Language: Memory and the Position of the Verb. A Corpus-Based Comparative Study of Interpreted and Non-mediated Speech
}

\section{Camille Collard, Heike Przybyl et Bart Defrancq}

Volume 63, numéro 3, décembre 2018

Traductologie de corpus : 20 ans après

URI : https://id.erudit.org/iderudit/1060169ar

DOI : https://doi.org/10.7202/1060169ar

Aller au sommaire du numéro

Éditeur(s)

Les Presses de l’Université de Montréal

ISSN

0026-0452 (imprimé)

1492-1421 (numérique)

Découvrir la revue

Citer cet article

Collard, C., Przybyl, H. \& Defrancq, B. (2018). Interpreting into an SOV Language: Memory and the Position of the Verb. A Corpus-Based Comparative Study of Interpreted and Non-mediated Speech. Meta, 63(3), 695-716. https://doi.org/10.7202/1060169ar

\section{Résumé de l'article}

En allemand et en néerlandais, le verbe se place après tous les éléments d'une proposition subordonnée (structure sujet-objet-verbe) et forme un champ médial (aussi appelé parenthèse verbale). Ce champ rend l'interprétation à partir d'une langue SOV vers une langue SVO particulièrement difficile puisqu'il augmente l'effort de traitement et de mémoire et exige de l'interprète qu'il recoure à des stratégies (l'anticipation par exemple) (Lederer 1981; Liontou 2011). Toutefois, peu d'études se penchent sur la problématique du point de vue des interprètes travaillant vers une langue SOV. Les structures SOV demandent un effort cognitif particulier pour le locuteur puisque, par exemple, les propriétés du sujet doivent être maintenues en mémoire pendant 10 à 20 mots pour permettre l'accord du verbe. Les locuteurs ont souvent recours à l'extraposition, une stratégie qui consiste à placer certains éléments après le verbe pour raccourcir la parenthèse (Hawkins 1994 ; Bevilacqua 2009). Les néerlandophones y auraient d'ailleurs recours plus fréquemment que les germanophones (Haeseryn 1990). L’interprétation générant un effort cognitif supplémentaire (Gile 1999), il est probable que les interprètes raccourcissent la parenthèse verbale plus fréquemment que les orateurs.

Dans cette étude, un corpus de discours originaux et d'interprétations au Parlement européen est analysé afin de comparer la longueur des parenthèses verbales dans des subordonnées allemandes et néerlandaises, ainsi que l'utilisation de l'extraposition. Les résultats tirés de 3460 subordonnées confirment la tendance des interprètes des deux langues à raccourcir le champ plus que les orateurs originaux. Ils montrent également que les interprètes germanophones ont recours à l'extraposition plus fréquemment que les orateurs originaux germanophones. Ce n'est toutefois pas le cas pour les interprètes néerlandophones. Enfin, les interprètes néerlandophones et germanophones semblent utiliser l'extraposition en partie parce qu'ils imitent l'ordre des mots des phrases du discours source, ce qui tend à montrer que l'extraposition est un outil permettant d'économiser l'effort cognitif.
Ce document est protégé par la loi sur le droit d'auteur. L’utilisation des services d’Érudit (y compris la reproduction) est assujettie à sa politique d'utilisation que vous pouvez consulter en ligne.

https://apropos.erudit.org/fr/usagers/politique-dutilisation/ 


\title{
Interpreting into an SOV Language: Memory and the Position of the Verb. A Corpus-Based Comparative Study of Interpreted and Non-mediated Speech
}

\author{
CAMILLE COLLARD \\ Ghent University, Ghent, Belgium \\ camille.collard@ugent.be
}

HEIKE PRZYBYL

Saarland University, Saarbrücken, Germany

heike.przybyl@uni-saarland.de

\author{
BART DEFRANCQ \\ Ghent University, Ghent, Belgium \\ bart.defrancq@ugent.be
}

\section{RÉSUMÉ}

En allemand et en néerlandais, le verbe se place après tous les éléments d'une proposition subordonnée (structure sujet-objet-verbe) et forme un champ médial (aussi appelé parenthèse verbale). Ce champ rend l'interprétation à partir d'une langue SOV vers une langue SVO particulièrement difficile puisqu'il augmente l'effort de traitement et de mémoire et exige de l'interprète qu'il recoure à des stratégies (l'anticipation par exemple) (Lederer 1981; Liontou 2011). Toutefois, peu d'études se penchent sur la problématique du point de vue des interprètes travaillant vers une langue SOV. Les structures SOV demandent un effort cognitif particulier pour le locuteur puisque, par exemple, les propriétés du sujet doivent être maintenues en mémoire pendant 10 à 20 mots pour permettre l'accord du verbe. Les locuteurs ont souvent recours à l'extraposition, une stratégie qui consiste à placer certains éléments après le verbe pour raccourcir la parenthèse (Hawkins 1994; Bevilacqua 2009). Les néerlandophones y auraient d'ailleurs recours plus fréquemment que les germanophones (Haeseryn 1990). L'interprétation générant un effort cognitif supplémentaire (Gile 1999), il est probable que les interprètes raccourcissent la parenthèse verbale plus fréquemment que les orateurs.

Dans cette étude, un corpus de discours originaux et d'interprétations au Parlement européen est analysé afin de comparer la longueur des parenthèses verbales dans des subordonnées allemandes et néerlandaises, ainsi que l'utilisation de l'extraposition. Les résultats tirés de 3460 subordonnées confirment la tendance des interprètes des deux langues à raccourcir le champ plus que les orateurs originaux. Ils montrent également que les interprètes germanophones ont recours à l'extraposition plus fréquemment que les orateurs originaux germanophones. Ce n'est toutefois pas le cas pour les interprètes néerlandophones. Enfin, les interprètes néerlandophones et germanophones semblent utiliser l'extraposition en partie parce qu'ils imitent l'ordre des mots des phrases du discours source, ce qui tend à montrer que l'extraposition est un outil permettant d'économiser l'effort cognitif.

\section{ABSTRACT}

In Dutch and German subordinate clauses, the verb is generally placed after the clausal constituents (Subject-Object-Verb structure) thereby creating a middle field (or verbal brace). This makes interpreting from SOV into SVO languages particularly challenging as it requires further processing and feats of memory. It often requires interpreters to 
use specific strategies (for example, anticipation) (Lederer 1981; Liontou 2011). However, few studies have tackled this issue from the point of view of interpreting into SOV languages. Producing SOV structures requires some specific cognitive effort as, for instance, subject properties need to be kept in mind in order to ensure the correct subject-verb agreement across a span of 10 or 20 words. Speakers therefore often opt for a strategy called extraposition, placing specific elements after the verb in order to shorten the brace (Hawkins 1994; Bevilacqua 2009). Dutch speakers use this strategy more often than German speakers (Haeseryn 1990). Given the additional cognitive load generated by the interpreting process (Gile 1999), it may be assumed that interpreters will shorten the verbal brace to a larger extent than native speakers.

The present study is based on a corpus of interpreted and non-mediated speeches at the European Parliament and compares middle field lengths as well as extraposition in Dutch and German subordinate clauses. Results from 3460 subordinate clauses confirm that interpreters of both languages shorten the middle field more than native speakers. The study also shows that German interpreters use extraposition more often than native speakers, but this is not the case for Dutch interpreters. Dutch and German interpreters appear to use extraposition partly because they imitate the clause word order of the source speech, showing that, in this case, extraposition can be considered an effort-saving tool.

\section{RESUMEN}

En alemán y en neerlandés, el verbo se coloca al final de la frase subordinada (estructura sujeto-objeto-verbo o SOV) constituyendo así una llamada zona mediana. La presencia de esta zona en lenguas de tipo SOV complica el proceso de interpretación a partir de lenguas de tipo SVO. Esto se debe a que el esfuerzo relacionado con el tratamiento de la información y la memorización aumenta, lo cual lleva al intérprete a aplicar determinadas estratégias como la anticipación (Lederer 1981; Liontou 2011). Pocos estudios se han dedicado al análisis de la interpretación hacia una lengua SOV. Estructuras de tipo SOV también causan un esfuerzo cognitivo considerable visto que la propiedades del sujeto tienen que mantenerse activas en la memoria durante $10 \circ 20$ palabras para que la congruencia del verbo se haga correctamente. Los hablantes recurren frecuentemente a la extraposición que consiste en colocar algunos elementos más allá del verbo para reducir la zona mediana (Hawkins 1994; Bevilacqua 2009). En neerlandés, la extraposición es más frecuente que en alemán (Haeseryn 1990). El presente estudio se basa en la hipótesis de que la reducción de la zona mediana por extraposición será más frecuente en actos de interpretación, por su esfuerzo cognitivo considerable.

El artículo actual propone un análisis basado en un corpus de discursos originales y sus interpretaciones en el Parlamento europeo, con el fin de comparar la extensión de las zonas medianas en frases subordinadas en neerlandés y en alemán y, en particular, la aplicación de la extraposición. En concreto, han sido analizados 3460 casos de frases subordinadas y los resultados confirman que intérpretes reducen la zona mediana más frecuentemente que los oradores del Parlamento europeo. Los resultados también confirman que los intérpretes hablantes alemanes $t$ usan más frecuentemente la estrategia de extraposición que los oradores del mismo idioma. Al revés, los intérpretes de habla neerlandesa no se distinguen de los oradores en este respecto. Finalmente, se comprueba que los intérpretes de ambas cabinas parecen utilizar la extraposición con el fin de imitar el orden de palabras del texto fuente, lo cual sugiere que la extraposición está instrumentalizada para reducir el esfuerzo cognitivo durante el proceso de interpretación.

\section{MOTS-CLÉS/KEYWORDS/PALABRAS CLAVE}

interprétologie sur corpus, effort cognitif, SOV, parenthèse verbale, extraposition corpus-based interpreting studies, cognitive effort, SOV, verbal brace, extraposition estudios de interpretación basados en el corpus, esfuerzo cognitivo, SOV, zona mediana, extraposición 


\section{Introduction}

Simultaneous interpreting is a demanding cognitive task (Gile 1999; Seeber 2011) in which interpreters need to find a balance between several simultaneous tasks: listening, analysis, memory, production and coordination. The different components of memory (short term, long term and working memory) play a key role in this process (Moser 1978; Darò and Fabbro 1994). Interpreters therefore tend to develop strategies to reduce their cognitive effort.

One of the most frequently mentioned contexts in which interpreters are said to need interpreting strategies is interpreting between languages with different word orders, in particular SOV-SVO. In one of the earliest studies on ear-voice-span (EVS), Oléron and Nanpon (1965/2002) find that EVS is shorter when interpreters work from English into French (both SVO) than when they work from German (SOV) into French (SVO). Goldman-Eisler (1972) attributes this difference to the position of the verb in German. Lederer (1981) refers in particular to word order differences when discussing anticipation as a strategy: as SVO languages need the verb to occur earlier in the sentence than SOV languages, interpreting from an SOV language (German) into an SVO language (French) puts the interpreter before a crucial strategic dilemma: either wait for the verb and halt delivery of all intermediary information, or try to guess what verb will be used and anticipate it. In his study on SOV-SVO interpreting, Bevilacqua (2009) offers a more comprehensive overview of strategies employed by interpreters to overcome structural differences between languages. Analysing interpreters' output, he finds evidence of anticipation, ear-voice span management, reformulation, compression and omissions. In terms of cognitive load attached to different strategies, Seeber (2011) models four different possible interpreter responses to SOV input while interpreting into an SVO language: waiting, stalling, chunking and anticipating. The first three strategies come with a high memory load, while the last one comes with an inherent risk of errors and subsequent cognitive load at the output end, if errors have to be corrected.

Studies in interpreting research have mainly tackled SOV-related strategies from the perspective of the recipient, focusing on the question how interpreters respond to SOV. With the exception of EVS-related issues, such as discussed in Lee (2002), the issue of how interpreters produce SOV structures on the basis of SVO input does not seem to have drawn interest from the research community. Yet, it may be expected that word order differences pose particular challenges to interpreters in both directions. Interpreters producing an SOV structure from an SVO input need to delay delivery of the verb until they reach the clause's particular final slot. This requires memory capacity and elicits cognitive load.

The lack of interest in SOV output in interpreting studies mirrors a more general tendency in the literature on memory: Acheson and McDonald (2009), for instance, express surprise over the one-sided focus on acquisition and reception in studies on working memory, as it is generally known that language production requires particular demands in terms of verbal working memory. However, early research on the effects of increased memory load and memory impairment on the production of spontaneous speech failed to produce significant results (Sternberg 1969; Shallice and Butterworth 1977; Klapp, Greim, et al. 1981; Vallar and Baddeley 1984), which may have discouraged most of the research community from pursuing research in that direction. 
In this paper, we set out to investigate interpreters' production of particular SOV patterns, that is to say verbal braces in subordinate clauses, to find out if the cognitive load inherent in the interpreting process affects the interpreters' output. We will focus particularly on the point of delivery of the verb within the pattern, comparing nonmediated language production (namely original speeches delivered at the European Parliament) and interpreted language. In section 2, we first describe the features of the SOV patterns in the languages under study, German and Dutch. Section 3 then combines this description with fundamental assumptions in interpreting to predict features of SOV patterns in interpreters' output. In section 4, we present the corpus materials used for this study and the methodology used to compare non-mediated output and interpreters' output. Results and conclusions drawn from the results are given in sections 5 and 6 .

\section{German and Dutch as SOV languages}

Dutch and German are often referred to as SOV languages (Gerritsen and Stein 1992; Eisenberg 1994) because the verbal group can be placed at the end of a clause. In canonical sentences with a simple verb, verbs are normally in second position following the subject or any other phrase, as illustrated in Example (1), where vandaag (today) is a temporal adjunct.

1) Vandaag werkt hij in de stad [today works he in town]

In canonical sentences with a complex verb and in subordinate clauses, the (main) verb is situated near the end of the sentence, as in Example (2).

2) Es ist besonders wichtig, dass wir den Dialog mit Russland fortführen [it is particularly important that we the dialog with Russia continue]

(EPICG_20080810_formal sitting1_Ingrid Betancourt_I_de)

This structure creates a verbal brace or bracket construction (Drach 1937/1963; Van Haeringen 1947; Haeseryn, Romijn, et al. 1997; Zwart 2011: 31-79) that divides the sentence into several fields. The verbal brace in Example (2) starts with the subordinating conjunction dass, hereafter also called left pole, and ends with the verb fortführen, hereafter called right pole. Three fields can be distinguished: the pre-field (Es ist besonders wichtig), the middle field (wir den Dialog mit Russland) and the after field, which is empty in this case. In written German and Dutch subordinates, the unmarked pattern consists of a middle field for clausal constituents, followed by the verb in clause-final position and an empty after field (Thurmair 1991: 175ff). Although the middle field (that is the field found inside the verbal brace) is considered the standard slot for clausal constituents both in German and Dutch, some of these constituents can occur in the after field. Their position is governed by a complex interaction of pragmatic, thematic, lexical and syntactic parameters (Jansen 1978; Vandenbosch 1985; Koops 1986; Braecke 1990; Zwart 19901; de Schutter 2003; Coussé 2009²; Willems 2017). Long and complex clausal constituents, for instance, tend to be placed in the after-field position, at least partially (Haeseryn, Romijn, et al. 1997). This phenomenon is called extraposition and is illustrated in Example (4), which is an adapted version of the real corpus example in (3): 
3) onze fractie denkt dat de enige manier om te zorgen voor stabiliteit euh en zekerheid aan beide kanten van de Atlantische Oceaan en te zorgen voor een evenwichtige samenwerking tussen de Europese Unie en de Verenigde Staten deze weg is [our group thinks that the only way to ensure stability and safety on both sides of the Atlantic Ocean and to ensure a balanced cooperation between the EU and the United States this way is

(EPICG_20080810_formal sitting1_Ingrid Betancourt_I_nl)

4) onze fractie denkt dat deze weg de enige manier is om te zorgen voor stabiliteit euh en zekerheid aan beide kanten van de Atlantische Oceaan en te zorgen voor een evenwichtige samenwerking tussen de Europese Unie en de Verenigde Staten

[our group thinks that this way the only way is to ensure stability and safety on both sides of the Atlantic Ocean and to ensure a balanced cooperation between the EU and the United States]

While in Example (3), the middle field contains 34 words and there is no after field, in Example (4) the middle field is reduced to 5 words, and an after field of 29 words is created. In between these two extremes, other options are available: is could, for instance, also be inserted just before en te zorgen.

Extraposition is available for most syntactic constituents except subject and object, where the length and complexity of the constituents increases the likelihood of extraposition. However, not only does the length of constituents play a role, the length of the middle field and of the after field also determine constituent placement. The longer the middle field, the more likely it is for constituents to be extraposed. Willems (2017) shows that this "overflow" capacity of the after field is not unlimited either: the longer it becomes, the less likely it is to be expanded yet further. Other linguistic parameters that have been found to promote extraposition in spoken Dutch are grammatical function (prepositional phrases are more prone to extraposition than adverbial adjuncts: Jansen 1978; Braecke 1990), and the indefiniteness of the noun included in the prepositional phrase (Jansen 1978). Extra-linguistic parameters are formal register, higher social class, older age and male gender (Jansen 1978; Braecke 1990).

Although Dutch and German have in principle the same possibilities to extrapose constituents, Dutch language users seem to do it more systematically than German speakers, who tend to preserve verbal braces instead (Haeseryn 1990). German therefore has a more rigid verb-final structure, while Dutch can be described as a "moderately verb-final SOV language" (de Schutter 1994: 466). In the interpreting data we used for this study, braces such as in Example (3) appeared to be more typical for German than for Dutch usage.

\subsection{SOV and extraposition in interpreting}

The challenges of interpreting from an SOV language into an SVO language are generally known and the effects on the interpreter's output are easily predictable: longer EVS and associated increased cognitive load, pausing, and anticipation. The question that interests us here is what to expect when interpreters are working from an SVO language into an SOV language.

It seems reasonable to assume that some additional memory effort will be needed, as interpreters will have to postpone delivery of the verb if they are interpreting from 
an SVO language. This is a cross-linguistic memory effort: its intensity partly depends on the position of the verb in the source language. However, not only must the verb be stored in memory, but also agreement features. In Example (3), for instance, the verb is, which agrees in person and number with its subject de enige manier, is separated from its subject by 26 words. The agreement features must consequently be stored in memory over a span of 26 words. Storing agreement features is a monolingual memory effort: its intensity depends on the position of the subject in the target language. Agreement features have been shown to be vulnerable in SOV contexts because of items occurring between the subject and the verb (Vigliocco 1998). The sooner a speaker delivers the verb, the lower the risk of agreement errors. The cross-linguistic effort is required of interpreters only; the monolingual memory effort concerns all users of the target language.

All in all, the total memory effort spent to interpret from an SVO language into an SOV language is likely to be smaller than when interpreting from SOV into SVO, as only the verb and agreement features have to be kept in memory and not all the clausal constituents that happen to occur in a verbal brace. In addition, extraposition offers interpreters a structural means of memory management: with some restrictions, constituents can be extraposed, narrowing down the gap between the verb in the target SOV language and its equivalent in the SVO source language, and between the verb and its subject in the target language. In other words, extraposition offers researchers a view on memory management in interpreters: comparing the point at which the verb is delivered in non-mediated language and in interpreting may reveal discrepancies that are significant for memory management in interpreters. As said, native speakers only face the memory effort related to the agreement features of the verb, while interpreters also have to cope with the cross-linguistic memory effort. To reduce the total memory effort, interpreters could be tempted to deliver the verb sooner than original speakers and, consequently, extrapose more often.

Before this hypothesis can be tested, we first need to check whether the parameters that determine extraposition in non-mediated language are likely to interact with interpreting processes in ways that would distort the results of a comparative analysis. As described above, the position of the verb in German and Dutch SOV structures is determined by a variety of linguistic and extra-linguistic factors. Among the linguistic factors, constituent length and complexity is likely to be different in non-mediated language and interpreting. Interpreting involves a higher cognitive load, for which interpreters are known to compensate by producing fewer long and complex constituents than non-interpreters, either because they omit non-essential source units (Shlesinger 2003) or because they apply some form of chunking (Meuleman and Van Besien 2009; Seeber 2011) to distribute the information over more but simpler constituents. As extraposition is more likely in the case of long and complex constituents, lower rates of long and complex constituents in interpreting could skew the data in favour of structures where the verb actually occurs later in interpreting than in non-mediated speech. Regarding the other linguistic factors, indefiniteness and grammatical function, there is no evidence to suggest that their frequencies are different in interpreted and non-mediated speech. They will not be considered confounding variables in this study.

As far as the extra-linguistic factors are concerned, sex could be a distorting factor, as the interpreting profession is predominantly female. Women have been 
shown to be more reluctant to extrapose constituents than men (Jansen 1978). Interestingly, this can be related to memory management. The female advantage in memory tasks is widely documented: women generally perform better than men in verbal and nonverbal memory tasks (Kramer, Delis, et al. 1997; Loonstra, Tarlow, et al. 2001; Kimura and Seal 2003; Maitland, Herlitz, et al. 2004). Assuming memory is a factor in extraposition, the greater propensity of men to extrapose constituents could be due to memory capacity. The question whether this sex difference is likely to show in interpreting data is undecided. The little research that has been carried out on differences between male and female interpreting has focused on sociolinguistic rather than cognitive properties (Magnifico and Defrancq 2016, 2017; Russo 2018). Mason (2008) found evidence for sex differences in omission rates for consecutive interpreters in the courtroom and Baes (2012) and Defrancq $(2013)^{3}$ discovered longer Ear-Voice-Span for female interpreters at the European Parliament. Cecot (2001) found that women used more filled pauses and men used more unfilled pauses. As far as memory differences are concerned, one could argue that these are likely to widen in activities such as interpreting, which put a particular strain on memory. On the other hand, it might also be argued that the intensive training which interpreters are offered, including memory training, is likely to close the gap between the sexes.

Besides sex, age and social class have also been shown to influence extraposition. Neither of these parameters is easy to control, for in interpreting research the number of participants in experimental research is always very limited, while in corpus research, data on the age and social class of interpreters are usually not available. We will assume that age and social class are not confounding variables in our study. The final parameter, formality, on the contrary, will have to be taken into account: interpreters usually operate in official contexts and are expected to use formal registers, which again could counterbalance a tendency to extrapose constituents.

Finally, in relation to interpreting in particular, it is also important to refer to source text influence as a factor determining the position of the verb. In a corpusbased study, De Sutter and Van de Velde (2008) found that Dutch translators of German prose extraposed significantly fewer prepositional phrases than Dutch authors. The opposite was however not true: German translators of Dutch prose did not extrapose more than German authors. This means that the source language can have an influence on the choice to extrapose constituents, but this influence could in turn be reinforced or inhibited by other factors. In our study, French is the source language for both the Dutch and German interpretations. French being an SVO language, all major constituents follow the verb, which could be an important trigger for extraposition.

In sum, the main hypothesis of the present study is that extraposition is more frequent in interpreting than in non-mediated speech because interpreters have an interest in delivering the verb sooner than original speakers. Some distorting factors that have been identified point towards less extraposition (a majority of female speakers and more formal registers), while the occurrence of specific interpreter strategies could lead to more extraposition (for example, anticipation). 


\section{Data and methodology}

\subsection{Corpus}

The data we use in this study are drawn from the European Parliament Interpreting Corpus Ghent (EPICG), supplemented with German data taken from the same context.

The choice of corpus data in interpreting research and, in particular corpus data from the European Parliament, is disputed. Diriker (2004), for instance, states that:

The online availability of the speeches and their interpretations at the EP's plenary sessions is certainly an invaluable source for researchers interested in analyzing authentic corpora of interpreting. Caution, however, is necessary, since the online availability of such recordings means they can be used by everyone, including researchers who have never seen the European Parliament in session nor talked to the interlocutors there to gain an idea of the constraints of interpreting in that particular setting. Although analysis of any data will by nature never be a mirror reflection of reality, drawing conclusions on SCI [Simultaneous Conference Interpreting] as situated action based on de-contextualized recordings must be taken with an even larger grain of salt. (Diriker 2004: 215)

Nevertheless, interpreting corpora are considered by many to have the potential to reinforce the empirical foundations of interpreting research (Shlesinger 1998). Corpus data are naturalistic data produced in a real-life environment by professionals and therefore reflect the interpreting activity in a way experimental data cannot. Corpora also give a more comprehensive view of the interpreting process and are more likely to produce reliable generalizations about the various interpreting activities.

The use of corpora is becoming increasingly popular in interpreting studies. New technologies have offered solutions to the time-consuming compilation, transcription and analysis of interpreting data. For several years, the plenary sessions and some of the committee sittings of the European Parliament can be downloaded from the website of the European Parliament. ${ }^{4}$ Plenary sessions may not be an entirely adequate response to the shortcomings of experimental data, as the interventions are generally very short (1 to 6 minutes), the source delivery rate is very high (155 words per minute on average), the speeches are often read out, and the working conditions only reflect this specific working environment. However, the amount of data allows for representative studies to be carried out on the context itself. The institutionalized setting of the debates furthermore ensures the homogeneity of the data in regard to the speakers' allocated time and the interpreters' qualification and working conditions. In addition, as both the non-mediated and the interpreted data are produced in the same context, it can reasonably be expected that there are no significant differences in levels of formality between both types of data. This ensures that one of the distorting factors mentioned in section 3 (formality) is controlled for. In the context of this study, we did not deem it necessary, as suggested by Diriker (2004), to re-contextualize the corpus data: the metadata collected as part of the corpus compilation effort (Bernardini, Collard, et al. 2017) suffice to gain a good understanding of the working conditions of EP interpreters.

The corpus is still being compiled at the time of writing of this study. Speeches are randomly selected on the European Parliament's website from plenary sessions between 2008 and 2013 and transcribed according to the Valibel instructions (Bachy, Dister, et al. 2007). ${ }^{5}$ Besides the words spoken, other acoustic features are included 
in the transcriptions (such as disfluencies, self-repairs, false starts, filled, and silent pauses). In its current shape, the corpus contains approximately 200,000-word tokens, with both source and target speech in English, French and Dutch. About half of the data of the EPICG are compiled in EXMARaLDA (Schmidt 2012). EXMARaLDA has the considerable advantage that transcriptions and audio can be aligned and that the software comes with a dedicated corpus compilation module and a concordancer.

The present study is based on a sub-corpus of EPICG and compares interpreted speeches with non-interpreted speeches. It comprises German and Dutch original speeches and German and Dutch interpretations of French source speeches. The Dutch data were extracted from the corpus; the German data were compiled specifically for this study. It was crucial to use interpretations from a third language, as using Dutch interpretations from German or vice versa could have yielded distorted data. De Sutter and Van de Velde (2008) indeed conclude on the basis of a literary corpus that Dutch translators appear to be influenced by the German source texts they translate, as verbal brace lengths are considerably longer in Dutch translations than in Dutch non-mediated literary production.

The sub-corpus contains 64 original speeches $(39$ speeches in German and 25 speeches in Dutch) and 76 interpretations from French (40 speeches in German and 36 speeches in Dutch). The total amount of tokens is $89,334(26,450$ tokens for German original speeches; 20,130 tokens for German interpretations from French; 19,200 tokens for Dutch original speeches and 23,554 tokens for Dutch interpretations from French). An attempt was made to create a balanced corpus by having the same number of mediated and non-mediated speeches, and by having the same French original speeches for both German and Dutch interpretations. However, it appears that the number of subordinates is higher in Dutch speeches. Therefore, the authors decided to add German mediated and non-mediated speeches in order to have a more balanced amount of subordinates in each group. The final corpus remains slightly unbalanced because it is almost impossible to predict how many subordinate clauses will be contained in a speech. Moreover, several speeches had to be deleted as it appeared that the interpreter was on relay, and not interpreting the speech directly from the source speech.

\subsection{Data selection}

\subsubsection{General principles}

The present study focuses on subordinate clauses because they always contain two poles, which is necessary to measure the length of the middle and after fields. In order to be able to clearly delineate the middle and after fields, only constructions starting with a subordinating conjunction (for example, Ik zei dat Jan morgen op tv komt in zijn eentje) or relative clauses (for instance, Hast Du die Lampe, die du gestern gesehen hast, gekauft?) have been taken into account. All relevant subordinates in the transcripts of German and Dutch originals as well as of interpreted speech were manually annotated by two independent researchers. Some subordinates were incomplete because either the left pole or (parts) of the verbal group were missing. Thus, in Example (5), a subordinate is clearly initiated by the subordinating conjunction dass. However, instead of completing the first clause with a verbal group, another subordinate is added. Such clauses were excluded from the dataset used for this study. 
5) [...] dass bei bestimmten wichtigen Punkten / die vor allem zu tun haben mit der Einrichtung einer europäischen Aufsichtsbehörde / oder auch mit / der / europäischen Registrierung und Zulassung euh euh von euh Wertpapierverwaltungsgesellschaften [...that for certain important points / which mainly have to do with establishing a European supervisory body / or also with European registration and certification of portfolio management companies]

(EPICG_20082209_Hedgefunds private equity_Pierre Jonckheer_I_nl)

The dataset also included examples where two or more subordinates shared the same left pole. In Example (6), for instance, the relative pronoun der triggers three subordinates:

6) ... der das Thema mit angesprochen hat mit auf die Tagesordnung gesetzt hat und damit den Beitrag geleistet hat

[... who the topic mentioned on the agenda put and a contribution made]

(EPICG_13012015_ Review of the Italian Presidency (debate)_Manfred

Weber_O_de)

Here, the number of words contained in the middle field was counted for each subordinate. We labelled this variable the "real middle field" (RMF). We analysed examples such as (6) as consisting of three different subordinates for which the RMF only contains the clausal constituents related to the verbal group. For this case: the RMF for the first subordinate is das Thema mit, for the second subordinate mit auf die Tagesordnung, and for the third damit den Beitrag. Items that could not have been used if there were only one subordinate clause, like the coordinating conjunction $u$ und in this example, were not included in the count.

After the filtering process, a total of 3460 instances of verbal braces in subordinate clauses were included in the study and distributed as shown in Table 1. Surprisingly, interpreters were found to produce more subordinate clauses than speakers.

TABLE 1

Distribution of subordinate clauses in the corpus

\begin{tabular}{|l|c|c|c|c|}
\hline & $\begin{array}{c}\text { German } \\
\text { non-mediated }\end{array}$ & $\begin{array}{c}\text { German } \\
\text { interpreted }\end{array}$ & $\begin{array}{c}\text { Dutch non- } \\
\text { mediated }\end{array}$ & $\begin{array}{c}\text { Dutch } \\
\text { interpreted }\end{array}$ \\
\hline No. of Token & 26,450 & 20,130 & 19,200 & 23,544 \\
\hline No. of Subordinates & 602 & 1014 & 659 & 1,185 \\
\hline $\begin{array}{l}\text { Subordinates per } \\
\text { 100 Token }\end{array}$ & 2.28 & 5.04 & 3.43 & 5.03 \\
\hline
\end{tabular}

The RMF was considered a proxy of the memory effort that was expended to produce the structure. Although using word counts to measure memory effort is not an ideal solution (in general, "chunks" or "information units" are considered better tools in this respect), these latter units lack precise definitions, and are not easy to identify in speech, where punctuation does not exist. Given this lack of clarity, for this study the word was chosen as a generally replicable unit.

However, it is also true that a more accurate representation of memory effort would be the span of words separating the subject from the verb. After all, the difference between SVO and SOV word order does not involve the position of the subject. Moreover, agreement features expressed on the verb are determined by the subject and must be kept in memory as soon as the subject is articulated. We never- 
theless opted for the RMF because quite a number of the examples extracted are subjectless, either because the clause is infinitival, or because its subject is the antecedent of a relative pronoun and thus outside the brace.

All fully pronounced words other than the right and left poles were counted. Hesitation markers such as euh, as in Example (7), truncated words or clear selfrepairs, as in (8), were not included in the word count.

7) ...dass $\frac{\text { euh / Fremdsprachen erlernt werden können }}{\mathrm{RMF}=1} \quad$

[...that euh / foreign languages can be learnt]

(EPICG_20080209_Explanations of vote_Astrid Lulling_I_nl)

8) ...dass die eigenen Krea/ Kreature entarten

[...that the own cre/ creatures degenerate]

(EPICG_20080810_formal sitting1_Ingrid Betancourt_I_nl)

RMF length provides us with an indication of memory effort, but it does not inform us about the use of strategies to manage memory capacity. As explained above, extraposition is viewed here as one of the strategies interpreters could use to avoid storage of information over comparatively long stretches of speech. We therefore counted the number of corpus examples in which extraposition is observed in nonmediated and in interpreted speech. For this, it was necessary to distinguish between items in the after field that theoretically could (or even should) be placed in the middle field and items that could not: only the former can be considered extraposed. We therefore employed the concept of the theoretical middle field (TMF) - comprising both the items found in the observed real middle field (RMF) and those in the after field (AF) that could have been placed in the middle field. ${ }^{6}$

Example (9) illustrates these concepts:

9) ...dass $\frac{\frac{\text { wir den Dialog fortführen }}{\mathrm{RMF}=3} \frac{\text { mit Russland }}{\mathrm{AF}=2}}{\mathrm{TMF}=\mathrm{RNF}+\mathrm{AF}=5}$

[...that we the dialog continue with Russia]

(EPICG_20080810_Formal sitting1_Ingrid Betancourt_I_de)

Here, the extraposed prepositional phrase in the after field mit Russland could have been placed in the middle field, therefore creating a theoretical middle field of 5 words.

All cases in which the number of words in the RMF is smaller than the number of words in the TMF are thus cases of extraposition, as in (10). If the RMF equals the TMF, there is no extraposition, as in (11), regardless of how many items the after field contains.

10) ...dus ik hoop dat dit programma / dan / in werking kan treden in januari 2009

\begin{tabular}{ll}
$R M F=5$ & $A F=3$ \\
\hline & $\mathrm{TMF}=\mathrm{RNF}+\mathrm{AF}=8$
\end{tabular}

[...so I hope that this program then into force can enter in January two thousand nine]

(EPICG_20082010_Erasmus Mundus_Marielle de Sarnez_I_nl) 
11) ...problemen die $\frac{\text { op dit moment geen oplossing }}{\mathrm{TMF}=\mathrm{RMF}=5}$
[...problems that at this moment no solution find $]$
(EPICG_20082110_EU-Russia relations_Jean-Pierre Jouyet_I_nl)

\subsubsection{Annotations}

To gain deeper insights from the data, we annotated them with additional features. Data on speaker and interpreter sex were drawn from the EPICG metadata to check whether sex differences in memory skills had an effect on the length of the verbal brace in interpreting, as compared to non-mediated speech. In the corpus metadata, sex was determined solely on the basis of perceived voice characteristics. According to most research, starting with Lass, Hughes, et al. (1976), this method is reliable: listeners are able, on the basis of vowels pronounced in isolation, to identify speaker sex with an accuracy of over $95 \%$.

Information on the structural properties of the source clauses was also included. Evidently, if the position of the verb in interpreted speech is determined by memory management, the position of the equivalent verb or clausal constituent in the source text is an important feature to take into account. As said before, French is an SVO language and all major constituents follow the verb. The cognitively least challenging solution for an interpreter is to produce speech that follows the source word order as closely as possible, within the limits of the target grammar. A French source is therefore a potential trigger for the extraposition of clausal constituents in German and Dutch interpreted speech. We examined to what extent this was the case in our data by analyzing whether the structure of the target clause ran parallel to that of the source clause in each occurrence of extraposition. Example (12) illustrates a case in which source and target structures are parallel; while in (13) the extraposed constituent does not have an equivalent in the source.

12) ...nous n'avons pas atteint les performances que nous souhaitions

[...we have not achieved the performances that we wished]

..., dass wir nicht die Leistungen erreicht haben die wir wünschten (German interpretation)

[...that we not the performances have achieved that we wished]

(EPICG_2008.08.10_Arctic governance_Michel Rocard_I_nl)

13) ...que bien des fois vous avez senti peut-être la frustration

[...that quite often you have felt maybe frustration]

...dass Sie häufig frustriert waren darüber (German interpretation)

[...that you often frustrated were about that]

(EPICG_20080810_formal sitting1_Ingrid Betancourt_I_de)

Evidently, examples such as (12) are more informative for memory strategies than (13). If extrapositions are triggered by the structural properties of the source clause, it could mean that interpreters to a certain extent sacrifice target acceptability to memory management: they deliver the verb closer to the position it occupies in the source text, even though this is not the most typical position in the target language. However, causality is impossible to establish in these cases: on the basis of our data we cannot tell whether interpreters extrapose because they are triggered by the source or for other reasons. 


\section{Results}

In the following sub-sections the results of the corpus analyses will be presented and discussed. We first compare non-mediated language and interpreting and then focus on interpreting.

\subsection{Length of the $R M F$}

Table 2 shows the results for the length of the real middle field in German nonmediated speech and interpreted speech, specifically the number of words between the subordinating conjunction and the verbal group. It appears that interpreters into German overall have a shorter RMF, both in terms of mean number of words and in terms of the median. The interpreters also present less variation than original speakers as a group.

TABLE 2

Real middle field length: German

\begin{tabular}{|l|c|c|c|c|c|c|}
\hline & N & Mean RMF & $\begin{array}{c}\text { Median } \\
\text { RMF }\end{array}$ & $\begin{array}{c}\text { Standard } \\
\text { Deviation }\end{array}$ & Minimum & Maximum \\
\hline German non-mediated & 602 & 5.41 & 4 & 4.291 & 0 & 29 \\
\hline German interpreted & 1014 & 4.27 & 3 & 3.366 & 0 & 26 \\
\hline
\end{tabular}

To check whether this difference is statistically significant, a visual inspection of the histograms in Figure 1 was carried out to determine what kind of statistical test would be appropriate.

FIGURE 1

RMF frequencies in German data

German non-mediated

German interpreted
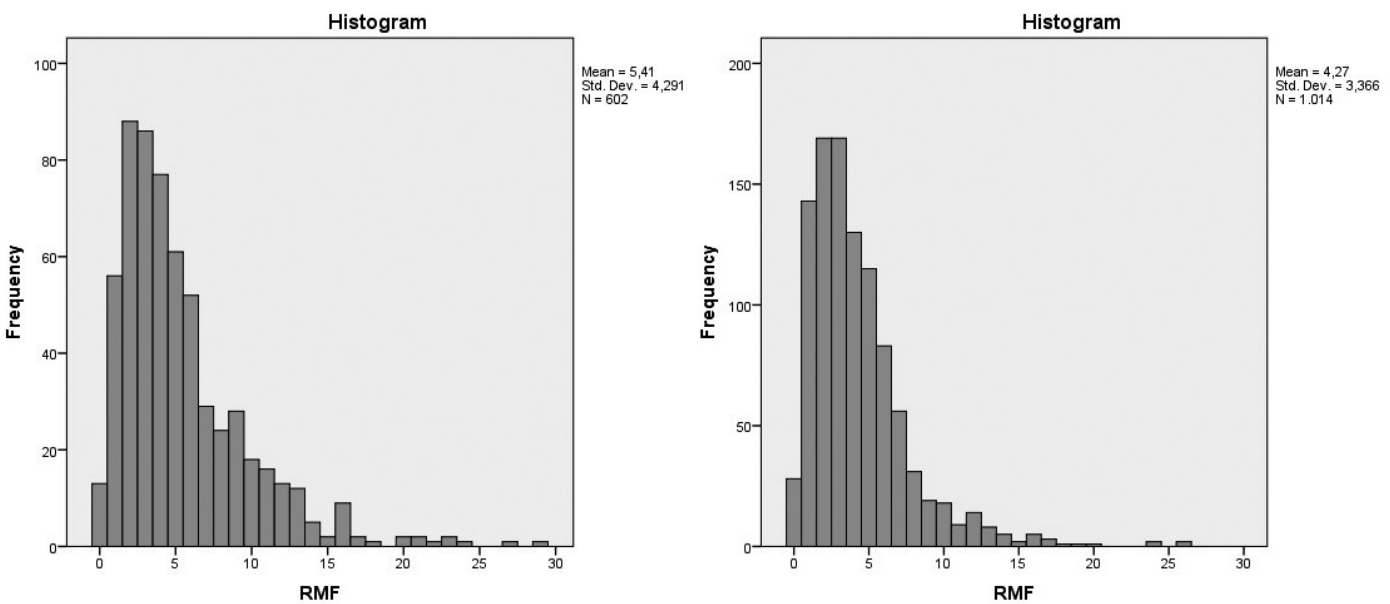
As the distribution for both groups is strongly skewed to the right, a non-parametrical Mann-Whitney U Test was performed on the data. The difference between original speakers and interpreters appears to be statistically highly significant $(\mathrm{U}=258115 ; p<0.001)$. This suggests that interpreting may have an impact on the memory efforts the German interpreters are prepared to expend: on average the RMF of interpreters is $21 \%$ or one full word shorter than that of native German speakers, with a mean length of 4.27 words as opposed to 5.41 words.

For Dutch, the data are presented in Table 3. Again, it appears that interpreters use shorter RMFs than native speakers, both in terms of mean length and in terms of the median. In the interpreted data, the mean RMF is $19 \%$ or almost a word shorter. As a group, interpreters also appear to act more homogeneously than original speakers.

TABLE 3

Real middle field length: Dutch

\begin{tabular}{|l|c|c|c|c|c|c|}
\hline & N & $\begin{array}{c}\text { Mean } \\
\text { RMF }\end{array}$ & $\begin{array}{c}\text { Median } \\
\text { RMF }\end{array}$ & $\begin{array}{c}\text { Standard } \\
\text { Deviation }\end{array}$ & Minimum & Maximum \\
\hline Dutch non-mediated & 659 & 4.49 & 4.00 & 3.519 & 0 & 22 \\
\hline Dutch interpreted & 1185 & 3.63 & 3.00 & 3.207 & 0 & 34 \\
\hline
\end{tabular}

As was the case for German, the distribution for both groups is strongly skewed to the right, requiring non-parametrical testing to determine whether the differences are significant.

\section{FIGURE 2}

\section{RMF frequencies in Dutch data}

Dutch interpreted

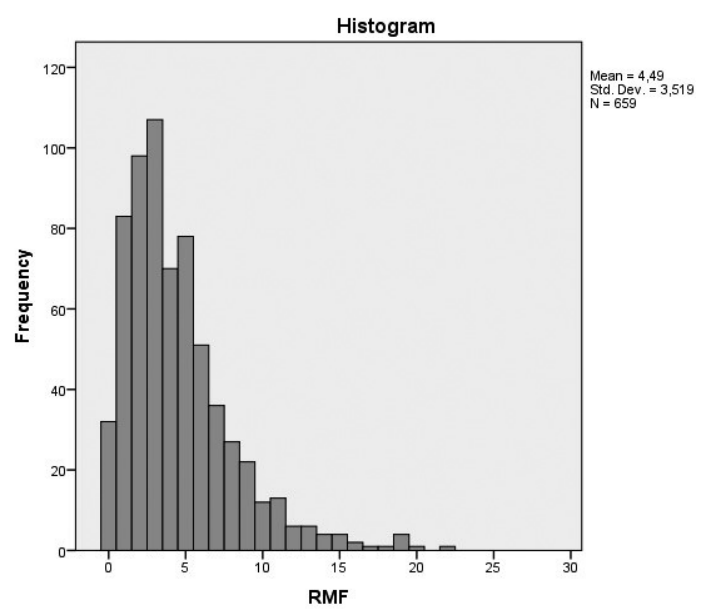

Dutch non-mediated

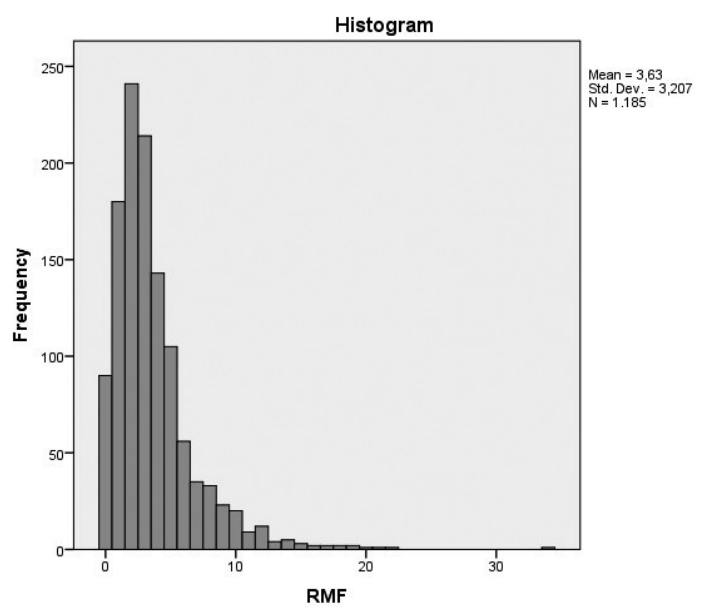

The Mann-Whitney U Test shows that the difference between Dutch interpreters and native speakers is statistically highly significant $(\mathrm{U}=326465.5 ; p<0.001)$.

As the results point in the same direction for both languages and the differences are in both cases highly significant, the tendency for interpreters to have a shorter 
RMF may be said to be robust. Furthermore, in both languages, interpreted RMFs are more homogeneous than non-mediated RMFs, even though there are more data for interpreters than for original speakers. This may indicate either that the shorter $\mathrm{RMF}$ is the result of a strategy interpreters commonly apply or that some sort of maximum memory capacity is reached, beyond which it becomes increasingly difficult to organize a verbal brace.

It also appears from Tables 2 and 3 and from Figure 3 that in both interpreted and non-mediated speech, German RMFs are longer than Dutch RMFs, confirming a tendency documented in the literature.

FIGURE 3

Mean RMF length in both varieties of German and Dutch

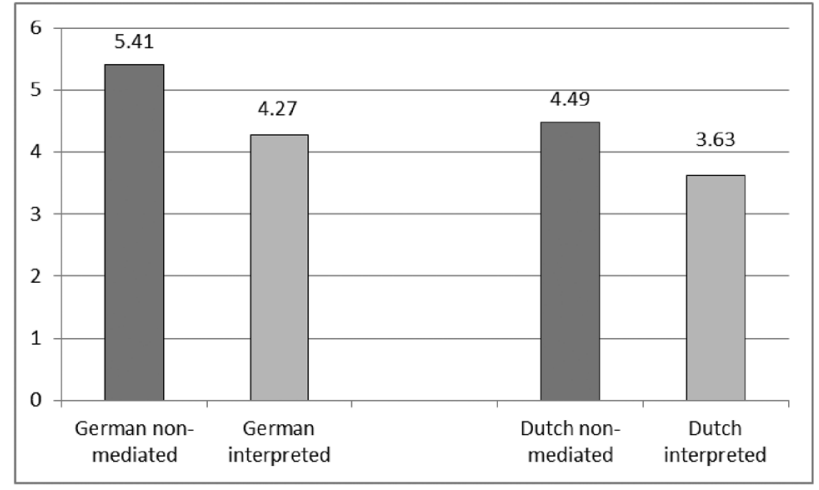

The differences are statistically highly significant for original speakers $(\mathrm{U}=174451.5 ; p<0.001)$ as well as for interpreters $(\mathrm{U}=514966.5 ; p<0.001)$. It is noteworthy in this respect that the mean RMF in interpreted German is shorter than in Dutch non-mediated speech.

Sex was reported to be an important extra-linguistic parameter in the positioning of the verb: on average, women tend to use the middle field more than men for prepositional phrases, making the middle field longer. The data from our sub-corpora, presented in Tables 4 and 5, confirm this general trend for native speakers, but not for interpreters.

TABLE 4

Sex differences in RMF length in German

\begin{tabular}{|l|c|c|c|c|c|c|}
\hline & N & $\begin{array}{c}\text { Mean } \\
\text { RMF }\end{array}$ & $\begin{array}{c}\text { Median } \\
\text { RMF }\end{array}$ & $\begin{array}{c}\text { Standard } \\
\text { Deviation }\end{array}$ & Minimum & Maximum \\
\hline Female non-mediated & 302 & 5.89 & 5.00 & 4.753 & 0 & 29 \\
\hline Male non-mediated & 300 & 4.92 & 4.00 & 3.715 & 0 & 24 \\
\hline Female interpreted & 820 & 4.12 & 3.00 & 3.238 & 0 & 26 \\
\hline Male interpreted & 194 & 4.89 & 4.00 & 3.807 & 0 & 26 \\
\hline
\end{tabular}


TABLE 5

Sex differences in RMF length in Dutch

\begin{tabular}{|l|c|c|c|c|c|c|}
\hline & N & $\begin{array}{c}\text { Mean } \\
\text { RMF }\end{array}$ & $\begin{array}{c}\text { Median } \\
\text { RMF }\end{array}$ & $\begin{array}{c}\text { Standard } \\
\text { Deviation }\end{array}$ & Minimum & Maximum \\
\hline Female non-mediated & 234 & 4.59 & 4.00 & 3.704 & 0 & 20 \\
\hline Male non-mediated & 425 & 4.43 & 4.00 & 3.415 & 0 & 22 \\
\hline Female interpreted & 716 & 3.54 & 3.00 & 3.165 & 0 & 34 \\
\hline Male interpreted & 469 & 3.76 & 3.00 & 3.268 & 0 & 21 \\
\hline
\end{tabular}

In both languages, mean RMF is longer in female non-mediated speech than in male. For German, this difference is significant $(\mathrm{U}=40393.5 ; p=0.02)$, but not for Dutch $(\mathrm{U}=49092 ; p=0.78)$. In interpreted speech, the opposite tendency is found: $\mathrm{RMF}$ in male interpretations is on average longer than in female. Again, the difference is statistically significant in German ( $U=69528$; $p<0.001)$, but not in Dutch ( $\mathrm{U}=162795.5 ; p=0.37)$.

There is no straightforward way to account for these observations. First, our findings for non-mediated data are supported by trends observed in other types of non-mediated speech and can easily be related to observed differences in memory skills. On the other hand, in activities which draw heavily on memory, such as interpreting, the female advantage seems to disappear. Training only seems to offer a partial explanation of this paradox: while the specific memory training interpreters receive and the daily practice of memory skills in their professional lives seems likely to level out sex differences to a certain extent, it does not explain why male interpreters should rely more on their memory placing the verb further away from the start of the clause and producing longer middle fields.

\subsection{Extraposition}

It has become clear that interpreters tend to unload their memories more than original speakers when it comes to producing verbal braces. The question that we try to answer in this section is whether they do so by means of extraposition. In other words, are the shorter RMFs the result of extraposition as a strategy to unload memory, or are the structures that interpreters produce just shorter overall?

Table 6 below shows the frequencies of structures with extraposition and structures without extraposition per language and speech type.

TABLE 6

Frequencies of extraposition per language and speech type

\begin{tabular}{|l|c|c|c|}
\hline & N & $\begin{array}{c}\text { Structures with } \\
\text { extraposition }\end{array}$ & $\begin{array}{c}\text { Structures without } \\
\text { extraposition }\end{array}$ \\
\hline German non-mediated & 602 & $84(13.9 \%)$ & $518(86.1 \%)$ \\
\hline German interpreted & 1014 & $225(22.2 \%)$ & $789(77.8 \%)$ \\
\hline Dutch non-mediated & 659 & $215(32.6 \%)$ & $444(67.4 \%)$ \\
\hline Dutch interpreted & 1185 & $408(34.4 \%)$ & $777(65.6 \%)$ \\
\hline
\end{tabular}


It appears that in all varieties, extraposition is the exception rather than the rule. Structures ending with the verb are at least twice as frequent as structures with extraposed constituents. As expected, extraposition is more popular in Dutch than in German. It is also significantly more popular among German interpreters than among native speakers (X-squared $=16,568 ; p<0.001$ ). In Dutch, the same trend can be observed, but the difference between interpreters and native speakers is nonsignificant (X-squared $=0.617 ; p=0.43$ ).

These results are not completely in line with the observations regarding the RMF. In German, the shorter RMF in interpreting can (at least partly) be explained by a higher frequency of extraposition: interpreters place the verb closer to the beginning of the clause than do original speakers. In Dutch, this is not the case: the RMF in interpreting is again significantly shorter, but this is not due to a more intensive use of extraposition. It seems that the only logical explanation is that Dutch interpreters produce significantly shorter clausal structures overall. ${ }^{7}$

Finally, we checked whether extraposition is subject to sex differences. The results are shown in Tables 7 and 8 .

TABLE 7

Sex differences in extraposition: German

\begin{tabular}{|l|c|c|c|}
\hline & N & Cases of extraposition & Cases of no extraposition \\
\hline Female non-mediated & 302 & $33(10.9 \%)$ & $269(89.1 \%)$ \\
\hline Male non-mediated & 300 & $51(17.0 \%)$ & $249(83.0 \%)$ \\
\hline Female interpreted & 820 & $184(22.4 \%)$ & $636(77.6 \%)$ \\
\hline Male interpreted & 194 & $41(21.1 \%)$ & $153(78.9 \%)$ \\
\hline
\end{tabular}

TABLE 8

Sex differences in extraposition: German

\begin{tabular}{|l|c|c|c|}
\hline & N & Cases of extraposition & Cases of no extraposition \\
\hline Female non-mediated & 234 & $77(32.9 \%)$ & $157(67.1 \%)$ \\
\hline Male non-mediated & 425 & $138(32.5 \%)$ & $287(67.5 \%)$ \\
\hline Female interpreted & 716 & $245(34.2 \%)$ & $471(65.8 \%)$ \\
\hline Male interpreted & 469 & $163(34.8 \%)$ & $306(65.2 \%)$ \\
\hline
\end{tabular}

As we can see, the percentages are similar between men and women, for all groups, and the Chi-Square tests show no statistically significant differences, except for German non-mediated speech where males use more extraposition than females (X-squared $=4.623 ; p=0.03$ ). A possible explanation may lie in the intensive memory training interpreters are exposed to during their training and their daily practice, which is likely to close the gap between the sexes.

\subsection{Influence of the source structure}

In this last section, we check to what extent the target word order in interpreting, extraposition in particular, is triggered by the structural properties of the source clause. If so, this would be evidence that interpreters prioritize memory management over target 
acceptability. Since structures with extraposition in an SOV language are structurally more similar to an SVO word order than structures without extraposition, the cognitively least demanding way to interpret SVO into SOV is to maximize extraposition. However, extraposition is not the preferred option in the target language and therefore raises acceptability issues. Table 9 presents the frequencies of extraposition in clauses that are structurally similar and dissimilar to the corresponding source clauses.

TABLE 9

Structural similarity of target extraposition and source clause word order

\begin{tabular}{|l|c|c|}
\hline & German interpreted & Dutch interpreted \\
\hline Structurally similar to source & $201(89.3 \%)$ & $369(90.4 \%)$ \\
\hline Structurally dissimilar to source & $23(10.2 \%)$ & $34(8.3 \%)$ \\
\hline Undetermined & $1(0.4 \%)$ & $5(1.2 \%)$ \\
\hline Total & 225 & 408 \\
\hline
\end{tabular}

In both languages, about $90 \%$ of extrapositions occur in contexts where they are potentially triggered by the word order in the source clause. This seems to suggest that interpreters do indeed use extraposition as a tool for memory management, following the source word order as closely as possible.

\section{Conclusions}

The aim of this study was to assess whether the increased cognitive effort of simultaneous interpreting had an influence on the position of the verb in SOV target languages. In an SOV language, the verb is placed at the end of the clause structure. In simultaneous interpreting from an SVO language into an SOV language, the verb therefore has to be stored in memory. The longer the middle field, the more effort is required to keep the verb stored. Given the additional cognitive load in interpreting, we hypothesized that interpreters would generally try to deliver the verb sooner than original speakers, keeping the middle field short and the memory effort as low as possible. Corpus data from EPICG and a collection of German transcriptions made specifically for this study supported this hypothesis for the two target languages involved (German and Dutch from French source speeches).

To find out whether the shorter middle field in interpreting is the result of a deliberate attempt to extrapose clausal constituents, we also checked whether extraposition is more frequent in interpreted than in non-mediated speech. This turned out to hold only for German, the difference in Dutch being negligible. This means that in German interpreting, the middle field is kept short by a more intensive use of extraposition - that is, delaying constituents and advancing the delivery of the verb -, while in Dutch interpreting, middle fields just consist of fewer elements. However, other factors such as a general tendency towards simplification in spoken language could have an influence on the use of extraposition and more research is needed in order to enable a clearer understanding of these results, find other potential factors, as well as to confirm the reliability of the chosen parameters.

We also hypothesized that, given the well-documented female advantage in memory skills and their presumably resulting tendency to fill up the middle field, 
female interpreters and female original speakers would both maintain longer middle fields than males. Although our results for non-mediated speech confirmed this general tendency, the interpreting data unexpectedly showed the opposite: male interpreters appear to maintain slightly longer middle fields than females. When it comes to the use of extraposition, no differences were found, except for German non-mediated speech, where males used more extraposition than females. A possible explanation may lie in the intensive memory training interpreters are exposed to during their training and their daily practice. However, this issue calls for further research as it seems unlikely that training and practice would have deeper effects on male than on female interpreters.

Finally, it was also examined whether extraposition was favoured by similarities in clause word order to that of the source. This appeared the case in a vast majority of the occurrences, providing evidence that interpreters use extraposition as a tool in memory management insofar as it enables them to stay as close as possible to the source word order.

\section{NOTES}

1. Zwart, Jan-Wouter (1990): PP Extraposition from NP in Dutch. Unpublished manuscript. Groningen: Universiteit Groningen. Visited 14 January 2018, <http://www.let.rug.nl/zwart/docs/ ppoverv.pdf $>$.

2. Coussé, Evie (2009): Changing word order in Dutch, unpublished. ICLaVE \#5: $5^{\text {th }}$ International Conference on Language Variation in Europe. Copenhagen, 25-27 May 2009.

3. DefrancQ, Bart (2013). Women and men interpreting, unpublished. Talking to the World: International Conference for the Interpreting Profession and Interpreter Education. Newcastle, 11-12 September 2013.

4. Plenary sessions. EPTV. Bruxelles: European Parliament. Visited 19 October 2017, <http://www. europarl.europa.eu/ep-live/en/plenary>.

5. BAChy, Sylvia, Dister, Anne, FranCARD, Michel, et al. (2007): Conventions de transcription régissant les corpus de la banque de données VALIBEL. Louvain-la-Neuve: Centre de recherche VALIBEL, Université catholique de Louvain.Visited 10 October 2015, <https://www.uclouvain.be/ cps/ucl/doc/valibel/documents/conventions_valibel_2004.pdf >.

6. Additional analyses were carried out with a stricter definition of the TMF (excluding all subordinate clauses from the TMF). Since the results were very similar, these analyses are not mentioned here.

7. Since the focus of this study is memory capacity, analyses were also carried out examining solely those cases where memory seems most at risk of being overloaded, that is, where the theoretical middle field is above average. Given that these analyses confirmed the other results, they are not discussed here.

\section{REFERENCES}

Acheson, Daniel and MacDonald, Maryellen (2009): Twisting tongues and memories: explorations of the relationship between language production and verbal working memory. Journal of Memory and Language. 60:329-350.

Baes, Eva (2012): Analyse des différences entre interprètes masculins et féminins au Parlement européen en termes de décalage. Master's thesis, unpublished. Ghent: Haute Ecole de Gand.

Bernardini, Sylvia, Collard, Camille, Russo, Mariachiara, et al. (2017): Building interpreting and intermodal corpora: A how-to for a formidable task. In: Mariachiara Russo, Claudio Bendazzoli, Bart Defrance, eds. Making Way in Corpus-based Interpreting Studies. Singapore: Springer.

BevilaCQUA, Lorenzo (2009): The position of the verb in Germanic languages and simultaneous interpretation. The Interpreters' Newsletter. 14:1-31. 
BRAECKe, Chris (1990): Uit de tang' of [+ or -] prominent [Out of the brace [+ or -] salient]? Taal en Tongval. 3:125-134.

Сесот, Michela (2001): Pauses in simultaneous interpretation: a contrastive analysis of professional interpreters' performances. The Interpreters' Newsletter. 11:63-85.

DARò, Valeria and FABBro, Franco (1994): Verbal memory during simultaneous interpretation: Effects of phonological interference. Applied Linguistics. 15:365-381.

De Schutter, Georges (1994): Dutch. In: König Ekkehard and Johan van der Auwera, eds. The Germanic Languages. London/New York: Routledge, 439-477.

De Schutter, Georges (2003): De zinsbouw in het vroege Middelnederlands. Een case study [Sentence structure in early Middle Dutch. A case study]. Taal en Tongval. 55:41-67

De Sutter, Gert and Van de Velde, Marc (2008): Do the mechanisms that govern syntactic choices differ between original and translated language? A corpus-based translation study of PP extraposition in Dutch and German. In: Richard XIAO, ed. Using Corpora in Contrastive and Translation Studies. Newcastle: Cambridge Scholars Publishing, 144-163.

DIRIKer, Ebru (2004): De-/Re-contextualizing Conference Interpreting: Interpreters in the Ivory Tower? Amsterdam/Philadelphia: John Benjamins.

DraCH, Erich (1937/1963): Grundgedanken der deutschen Satzlehre [Basic concepts of German syntax]. Darmstadt: Wissenschaftliche Buchgesellschaft.

Eisenberg, Peter (1994): German. In: König EkKehard and Johan van der Auwera, eds. The Germanic Languages. London/New York: Routledge, 349-387.

Gerritsen, Marinel and Stein, Dieter, eds. (1992): Internal and External Factors in Syntactic Change. Berlin: Mouton de Gruyter.

GILE, Daniel (1999): Testing the Effort Models' tightrope hypothesis in simultaneous interpreting - a contribution. Hermes. 23:153-172.

GoldMAN-EIsLER, Frieda (1972): Segmentation of input in simultaneous interpretation. Journal of Psycholinguistic Research. 1:127-140.

HAESERYN, Walter (1990): Syntactische normen in het Nederlands. Een empirisch onderzoek naar volgordevariatie in de werkwoordelijke eindgroep [Syntactic norms in Dutch. An empirical study on variations in the word order of the verbal final group]. Doctoral dissertation, unpublished. Nijmegen: Radboud University Nijmegen.

HAESERYN, Walter (1997): Achteropplaatsing van elementen in de zin [Extraposition of elements in the sentence]. Colloquium Neerlandicum. 13:303-326.

Haeseryn, Walter, Romijn, Kirsten, Geerts, Guido, et al. (1997): Algemene Nederlandse Spraakkunst [Grammar of general Dutch]. Groningen/Deurne: Martinus Nijhoff/Wolters Plantyn.

Hawkins, John (1994): A Performance Theory of Order and Constituency. Cambridge: Cambridge University Press.

Jansen, Frank (1978): Hoe krijgt een spreker zijn woorden op een rijtje? Taalgebruiksaspekten van de 'PP over V' konstruktie [How does a speaker get his words in the right order? Aspects of language use for "PP over V" constructions]. In: Jan KooIJ, ed. Aspekten van de woordvolgorde in het Nederlands [Aspects of word order in Dutch]. Leiden: Vakg, 70-104.

Kimura, Doreen and SEAL, Brooke (2003): Sex differences in recall of real or nonsense words. Psychological Reports. 93:263-264.

Klapp, Stuart, Greim, David, and Marshburn, Elizabeth A. (1981): Buffer storage of programmed articulation and articulatory loop: Two names for the same mechanism or two distinct components of short-term memory? In: John LONG and Alan BADdeley, eds. Attention and Performance IX. Hillsdale: Erlbaum, 459-472.

Koops, Wieber (1986): Multiphasic growth curve analysis. Growth. 50:169-177.

Kramer, Joel, Delis, Dean, Kaplan, Edith, et al. (1997): Developmental sex differences in verbal learning. Neuropsychology. 11:577-584.

Lass, Norman, Hughes, Karen, Bowyer, Melanie D., et al. (1976): Speaker sex identification from voiced, whispered, and filtered isolated vowels. Journal of the Acoustical Society of America. 59:675-678.

Lederer, Marianne (1981): La traduction simultanée. Paris: Minard Lettres Modernes. 
LeE, Tae-Hyung (2002): Ear-Voice-Span in English into Korean simultaneous interpreting. Meta. 47(4):596-606.

Liontou, Konstantina (2011): Strategies in German-to-Greek simultaneous interpreting: A corpus-based approach. Gramma. 19:37-56.

Loonstra, Ann, Tarlow, Alison, and Sellers, Alfred H. (2001): COWAT metanorms across age, education and gender. Applied Neuropsychology. 8(3):161-166.

Magnifico, Cedric and DefrancQ, Bart (2017): Hedges in conference interpreting: The role of gender. Interpreting. 19(1):21-46.

Magnifico, Cedric and DefrancQ, Bart (2016): Impoliteness in interpreting: a question of gender? Translation and Interpreting. 8(2):26-45

Mason, Marianne (2008): Courtroom Interpreting. Lanham/Plymouth: University Press of America.

Maitland, Scott, Herlitz, Agneta, Nyberg, Lars, et al. (2004): Selective sex differences in declarative memory. Memory \& Cognition. 32(7):1160-1169.

Meuleman, Chris and Van Besien, Fred (2009): Coping with extreme speech conditions in simultaneous interpreting. Interpreting. 11(1):20-34.

Moser, Barbara (1978): Simultaneous interpretation: A hypothetical model and its practical application. In: David Gerver and Wallace Sinaiko, eds. Language Interpretation and Communication. New York/London: Plenum Press, 353-368.

Oléron, Pierre and NANPON, Hubert (1965/2002): Research into simultaneous translation. In: Franz PöchH ACKer and Miriam Shlesinger, eds. The Interpreting Studies Reader. London/ New York: Routledge, 69-76.

Russo, Mariachiara (2018): Speaking Pattern and Gender in the European Parliament Interpreting Corpus: A Quantitative Study as a Premise for Qualitative Investigations. In: Mariachiara Russo, Claudio Bendazzoli, and Bart Defrance, eds. Making Way in Corpus-based Interpreting Studies. Singapore: Springer, 115-132.

Schmidt, Thomas (2012): EXMARaLDA and the FOLK tools. In: Thierry Declerck, Khalid Choukri, and Nicoletta Calzolari, eds. Proceedings of the Eighth conference on International Language Resources and Evaluation. (LREC 2012: Eighth conference on International Language Resources and Evaluation, Istanbul, 23-25 May 2012). Paris: European Language Resources Association, 236-240.

SEeber, Kilian (2011): Cognitive load in simultaneous interpreting: Existing theories - new models. Interpreting. 13(2):176-204.

Shallice, Tim and Butterworth, Brian (1977): Short-term memory impairment and spontaneous speech. Neuropsychologia. 15:729-735.

Shlesinger, Miriam (1998): Corpus-based interpreting studies as an offshoot of corpus-based translation studies. Meta. 43:486-493.

Shlesinger, Miriam (2003): Effects of presentation rate on working memory in simultaneous interpreting. The Interpreter's Newsletter. 12:37-49.

Sternberg, Saul (1969): Memory scanning: Mental processes revealed by reaction-time experiments. American Scientist. 4:421-457.

Thurmair, Maria (1991): Warten auf das Verb. Die Gedaechtnisrelevanz der Verbklammer im Deutschen [Waiting for the verb. The relevance of memory for the verbal parenthesis in German]. Jahrbuch Deutsch als Fremdsprache. 17:174-202.

VAllar, Giuseppe and BAdDEley, Alan (1984): Fractionation of working memory. Neuropsychological evidence for a phonological short-term store. Journal of Verbal Learning and Verbal Behaviour. 23:151-162.

VAndenbosch, Luc (1985): PpoverV: een funktioneel-pragmatisch principe [Pp over V: a functional-pragmatic principle]. Antwerp Papers in Linguistics. 46:1-72.

VAn Haeringen, Coenraad (1947): Tangconstructies' en reacties daarop [Brace constructions and perceptions]. De Nieuwe Taalgids. 40:1-7.

VigLiocco, Gabriella (1998): Separating hierarchical relations and word order in language production: Is proximityconcord syntactic or linear? Cognition. 68:13-29. 
Willems, Annelore (2017): Uit het veld geslagen: een corpusgebaseerd multivariaat onderzoek naar de positie van voorzetselconstituenten in de Nederlandse journalistieke bijzin [Out of the field: a multivariable corpus-based study on the position of preposition's constituents in Dutch journalistic subordinate clauses]. Doctoral dissertation, unpublished. Ghent: Ghent University.

ZwarT, Jan-Wouter (2011): The Syntax of Dutch. Cambridge: Cambridge University Press. 